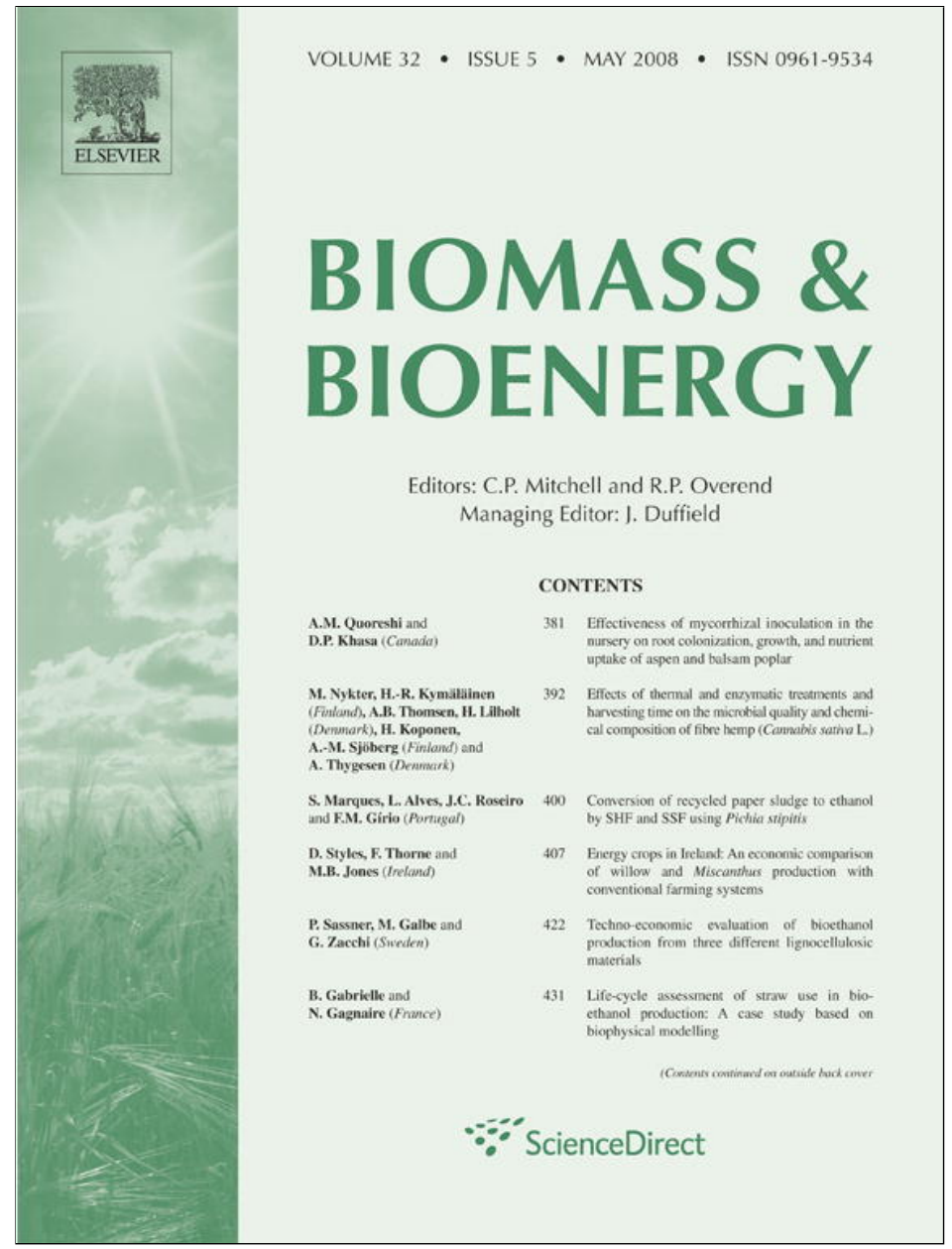

This article appeared in a journal published by Elsevier. The attached copy is furnished to the author for internal non-commercial research and education use, including for instruction at the authors institution and sharing with colleagues.

Other uses, including reproduction and distribution, or selling or licensing copies, or posting to personal, institutional or third party websites are prohibited.

In most cases authors are permitted to post their version of the article (e.g. in Word or Tex form) to their personal website or institutional repository. Authors requiring further information regarding Elsevier's archiving and manuscript policies are encouraged to visit:

http://www.elsevier.com/copyright 


\title{
Energy crops in Ireland: An economic comparison of willow and Miscanthus production with conventional farming systems
}

\author{
David Styles $^{a, *}$, Fiona Thorne ${ }^{b}$, Michael B. Jones ${ }^{a}$ \\ ${ }^{a}$ Botany, School of Natural Sciences, Trinity College Dublin, Dublin 2, Ireland \\ ${ }^{b}$ Rural Economy Research Centre, Teagasc, Malahide Road, Dublin 17, Ireland
}

\section{A R T I C L E I N F O}

Article history:

Received 15 May 2006

Accepted 26 October 2007

Available online 11 December 2007

Keywords:

Miscanthus

Willow

Energy crops

Net present value

Gross margins

Economics

\begin{abstract}
A B S T R A C T
Recent full decoupling of EU agricultural subsidy payments from production in Ireland is forecast to result in substantial destocking of grassland over the coming decade. In conjunction with increased energy prices, this presents new opportunities for energy crops. This paper uses extensive literature review and country-specific information on current prices to construct life-cycle cost assessments for production of Miscanthus and shortrotation coppice willow (SRCW) in Ireland. Gross margins for different harvest and supply strategies (e.g. chopped or baled harvest for Miscanthus; stick or chipped harvest for SRCW) are calculated based on farm-gate biomass prices equivalent to 70, 100 and $130 € \mathrm{t}^{-1} \mathrm{dry}$ matter (DM) at maximum 20\% moisture content-reduced for some SRCW supply strategies to reflect additional chipping and transport costs, and lower heating values. These are compared with gross margin projections for conventional agricultural systems (dairy, cattle rearing, 'cattle and other', sugar beet, winter wheat, spring barley and set aside) using a net present value approach. Production costs expressed per tonne DM were similar for Miscanthus (€37-48) and SRCW (€31-46). Mid-estimate discounted, annualised gross margins ranging between 326 and $383 € \mathrm{ha}^{-1}$ for Miscanthus, and between 211 and $270 € \mathrm{ha}^{-1}$ for SRCW, compared favourably with all conventional agricultural systems considered except dairy. These gross margins were based on peak-productivity combustible yields of 14 and $10 \mathrm{tDM} \mathrm{ha}^{-1} \mathrm{a}^{-1}$ for Miscanthus and SRCW. Yield variation will affect gross margins, but low yields were still calculated to realise positive returns. However, the application of high-activity cost estimates for all energy-crop cultivation activities resulted in negative returns for some supply strategies. Recently announced government support for SRCW and Miscanthus considerably reduces investment risk for farmers, whilst utilisation of SRCW to treat waste water could substantially increase revenues. Energy crop cultivation has the potential to offer farmers a modestly profitable alternative to declining returns from conventional land uses.
\end{abstract}

(c) 2007 Elsevier Ltd. All rights reserved.

\footnotetext{
${ }^{*}$ Corresponding author. Tel.: +35316083068 .

E-mail address: dstyles@tcd.ie (D. Styles). 0961-9534/\$ - see front matter (c) 2007 Elsevier Ltd. All rights reserved.
} doi:10.1016/j.biombioe.2007.10.012 


\section{Introduction}

In 2004, Irish greenhouse gas (GHG) emissions were 25\% higher than 1990 levels [1], significantly exceeding Ireland's Kyoto Commitment to a maximum GHG emission increase of 13\% above 1990 levels over the 2008-2012 commitment period. As a consequence, Ireland will be required to pay hundreds of millions of euro, either in penalties or towards GHG emission reduction schemes in developing countries. Of the $68.5 \mathrm{Mt}$ carbon dioxide equivalents ( $\mathrm{CO}_{2}$ eq.) emitted in Ireland in 2004, 28\% were attributable to agriculture [1]. This reflects the large agricultural land area $(4.3 \mathrm{Mha})$ relative to population size (4.24M people), and the dominance of livestock production within the agricultural sector [2]. Grassland supporting sheep and cattle systems account for $83 \%$ of agricultural land area [2] and result in the emission of the potent GHGs methane and nitrous oxide. Approximately $22 \%$ of 2004 GHG emissions were attributable to electricity production, and a further $22 \%$ to the heating of domestic, commercial and public buildings [3]. Styles and Jones [4] demonstrate the substantial national GHG emission savings possible through the co-firing of energy crop biomass in existing peat and coal power stations, accounting for both displaced livestock production and substituted coal and peat electricity production. Similar savings are possible through the utilisation of energy crop biomass for heating [5].

Recently in the republic of Ireland, the debate regarding the future role of energy crop production has heightened in direct response to a number of issues. Firstly, in response to the reform of the EU Common Agricultural Policy (CAP), Ireland replaced production-indexed farm subsidies with production'decoupled' single farm payments (SFP) in 2005, based on land area farmed during 2000-2002. Economic modelling of farmlevel response to this decoupling of direct payments has indicated that livestock numbers will decline significantly (i.e. $21 \%$ reduction in dairy cows; $10 \%$ reduction in non-dairy cattle; 26\% reduction in sheep numbers from 2002 to 2012 [6]). The land areas dedicated to both cereal production and sugar beet (in response to a reduction in EU sugar-beet price support) are also forecast to decline $[7,8]$. Secondly, dramatic increases in oil and gas prices have recently made fossilbased electricity and heat production substantially more expensive. These high prices may reflect a new era of higher energy costs perpetuated by limitations in the rate of oil supply and rapidly increasing demand from the growing economies of China and India. Thirdly, the introduction of the EU Emission Trading Scheme (ETS) in 2005, with future $\mathrm{CO}_{2}$ allowances trading at approximately $€ 15 \mathrm{t}^{-1} \mathrm{CO}_{2}$ for 2008 [9], will further increase the costs incurred by large-scale fossil-fuel combustion, and provide financial incentives for carbon-neutral fuels, including biomass, under the EU ETS legislation $[10,11]$. The competitive economics of Miscanthus co-firing in peat power stations, and willow wood chip heating in domestic and small-commercial dwellings, are outlined in [12].

One key determinant of whether Ireland will fully respond to the aforementioned drivers for change is the presence of a strong and apparent economic incentive for farmers to become producers of energy crops. Deurwaarder [13] identified uncertainty regarding the cost effectiveness of biofuel production in Europe as one of the major impediments to the development of the sector. There has been no published research on the comparative economics of energy crop production in the republic of Ireland in the recent past. Without some assessment of the economic value of these crops, the future development of bioenergy crops in this region remains uncertain. While similar studies have been undertaken in other countries [14-16], and in N. Ireland $[17,18]$, there is significant scientific merit in establishing work that will specifically determine the potential role of indigenous energy crop production in the republic of Ireland. Hence, this paper explores the current economic outlook for the production of energy crops in Ireland, particularly considering competitiveness with conventional agricultural land uses. The energy crops considered are the fast-growing and high-yielding short-rotation coppice willow (SRCW) and Miscanthus $\times$ giganteus (also referred to as Elephant grass). As of early 2007, these crops became eligible for new government planting and maintenance subsidies (detailed below) [19].

\section{Methodology}

\subsection{Life-cycle cost assessment}

Life-cycle cost assessments for 23-year, 7-cut SRCW, and 16 year, 14-cut Miscanthus plantations were conducted, based on the farm operation sequences shown in Table 1, and for each of the supply strategies listed in Table 2. Costs for each activity were taken from the literature, and converted to 2006 prices (Table 3) using inflation rates for agricultural inputs up until 2004 [2], and FAPRI-Ireland projections for variable-cost inflation thereafter (Fig. 1). This ensured accurate comparison with FAPRI-Ireland projections for conventional agricultural system gross margins after 2004. Activities outlined in Table 1, and yields outlined in Table 4, are identical to those applied in a previous paper [4], in which life-cycle analysis was used to identify the GHG emission reductions possible through Miscanthus and SRCW utilisation.

Fertiliser application rates of 100:20:100 $\mathrm{kg} \mathrm{ha}^{-1} \mathrm{a}^{-1} \mathrm{~N}: \mathrm{P}: \mathrm{K}$ were used for Miscanthus, following maximum rates suggested by [20]. This covers the crop off-takes of 88, 11 and $95 \mathrm{~kg} \mathrm{~N}, \mathrm{P}$ and $\mathrm{K}$ per hectare in $13.5 \mathrm{t}$ dry matter (DM) stems as calculated by [21], and is greater than the 80,10 and $60 \mathrm{~kg} \mathrm{ha}^{-1} \mathrm{a}^{-1}$ replenishment rate used by [22]. Also shown in Table 3 is an estimate of cultivation costs based on new contracts provided by the first Irish agricultural contractor to specialise in Miscanthus [23]. They 'guarantee' both successful establishment for a cost of $€ 2470 \mathrm{ha}^{-1}$ to the farmer, and a crop price of approximately $€ 50 \mathrm{t}^{-1}$ at up to $20 \%$ moisture content $\left(€ 63 \mathrm{t}^{-1} \mathrm{DM}\right)$. Miscanthus plantations may maintain high productivity for up to 20 years after planting [20,24], but the conservative assumption of a 15-year productive lifetime was applied here (Table 1). Herbicide application on established SRCW plantations is highly dependent on local circumstances, and in many instances may not be necessary due to rapid canopy closure once the crop is established, and the beneficial effect of some ground cover. Here, it was assumed that worst-case scenario herbicide costs of $€ 75 \mathrm{ha}^{-1}$ 
Table 1 - Life cycle activities for SRCW and Miscanthus cultivation, as applied to LCA in [4], and to life-cycle cost assessment in this paper

\begin{tabular}{|c|c|c|c|}
\hline Year & SRCW & Year & Miscanthus \\
\hline 0 & $\begin{array}{l}\text { Herbicide application } \\
\text { Subsoiling and ploughing }\end{array}$ & 0 & $\begin{array}{l}\text { Herbicide application } \\
\text { Subsoiling and ploughing }\end{array}$ \\
\hline \multirow[t]{5}{*}{1} & $\begin{array}{c}\text { Herbicide and insecticide (leather jacket control) } \\
\text { application }\end{array}$ & 1 & Fertiliser application $\left(67,13\right.$ and $67 \mathrm{~kg} \mathrm{ha}^{-1} \mathrm{~N}, \mathrm{P}$ and $\left.\mathrm{K}\right)$ \\
\hline & Lime application $\left(3 \mathrm{tha}^{-1}\right)$ & & Lime application $\left(3 \mathrm{tha}^{-1}\right)$ \\
\hline & Soil rotovation & & Soil rotovation \\
\hline & $\begin{array}{l}\text { Planting using a step or cabbage planter at density of } \\
15,000 \text { cuttings per ha }\end{array}$ & & Planting, potato planter at density of 20,000 rhizomes per ha \\
\hline & & & Rolling \\
\hline \multirow[t]{2}{*}{2} & Coppice & & Herbicide application \\
\hline & $\begin{array}{c}\text { Fertiliser application }\left(128,28 \text { and } 178 \mathrm{~kg} \mathrm{ha}^{-1} \mathrm{~N}, \mathrm{P} \text { and } \mathrm{K}\right) \\
\text { Herbicide application }\end{array}$ & 2 & Fertiliser application $\left(67,13\right.$ and $67 \mathrm{~kg} \mathrm{ha}^{-1} \mathrm{~N}, \mathrm{P}$ and $\left.\mathrm{K}\right)$ \\
\hline \multirow[t]{2}{*}{5} & $\begin{array}{c}\text { Stick/chip harvest late winter (i.e. winter year 4/5) } \\
\text { Drying }^{\mathrm{a}} \\
\text { Storage on farmb }\end{array}$ & & $\begin{array}{c}\text { Cut and bale/chop harvest late winter } \\
\text { Drying }^{\mathrm{a}} \\
\text { Storage on } \text { farm }^{\mathrm{b}}\end{array}$ \\
\hline & $\begin{array}{c}\text { Fertiliser application (192, } 42 \text { and } 267 \mathrm{~kg} \mathrm{ha}^{-1} \\
\text { N, P and K) } \\
\text { Herbicide application }\end{array}$ & $3-15$ & $\begin{array}{c}\text { Repeat year 2, but apply fertiliser at 100:20:100 } \mathrm{kg} \mathrm{ha}^{-1} \mathrm{~N}, \mathrm{P} \text { and } \\
\text { K from year } 4 \text { onwards }\end{array}$ \\
\hline 8 & $\begin{array}{c}\text { Late winter harvest (i.e. winter year 7/8) } \\
\text { Drying }{ }^{\mathrm{a}} \\
\text { Storage on farm }{ }^{\mathrm{b}}\end{array}$ & 16 & Apply herbicide to new growth and plough \\
\hline 9-22 & Repeat year $5-8$ rotation 5 more times & & \\
\hline 23 & Remove stools & & \\
\hline $\begin{array}{l}\text { a Dry } \\
\text { b Stor }\end{array}$ & $\begin{array}{l}\text { epends on harvest method, storage and end use. } \\
\text { ependent on harvest method and end use. } \\
\text { every other rotation. }\end{array}$ & & \\
\hline
\end{tabular}

Table 2 - Harvest and supply strategy abbreviations and descriptions for SRCW and Miscanthus

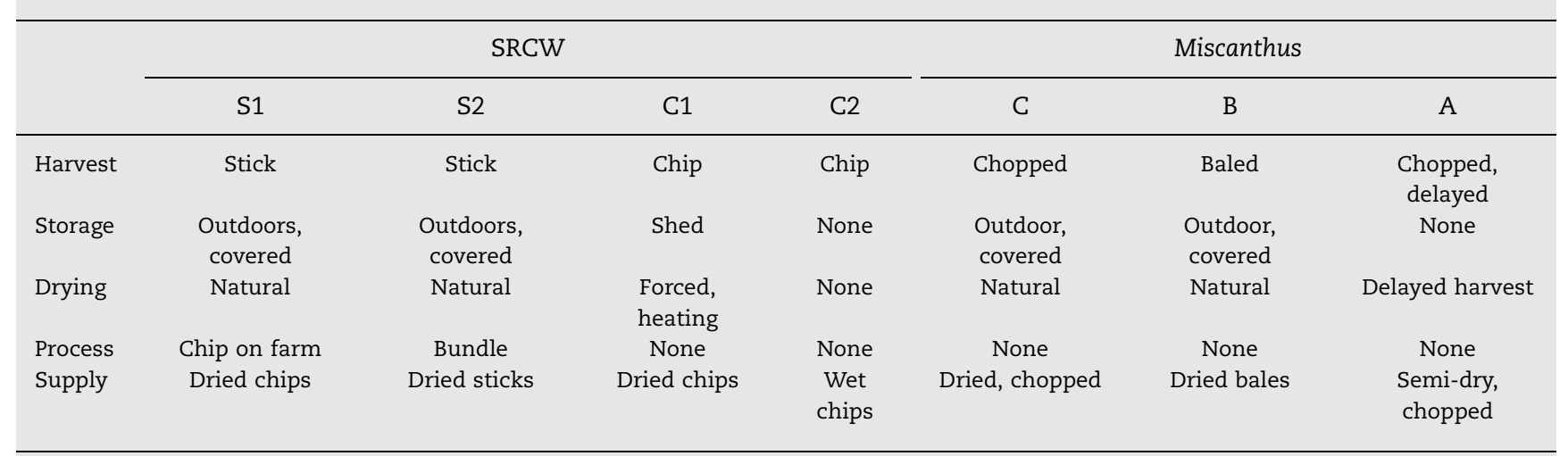

are incurred every other harvest cycle [25]. Herbicide application is considered necessary only in the establishment year for Miscanthus, as leaf-litter ground cover and rapid canopy closure were assumed to suppress weed growth [21].

The 2006 cost estimates shown in Table 3 include low-, midand high-cost estimates for each activity, representing the range of values found in the literature. These were used to generate low-, mid- and high-production cost estimates, denoted by the suffices ' $a$ ', ' $b$ ' and ' $c$ ', respectively, applied to supply strategy labels (e.g. S1b refers to mid-cost stick harvest and supply). The most appropriate values were chosen for the 'mid-cost' estimates, based on similarity to Irish circumstances and contemporaneousness. In some instances, it was possible to find only one or two values for specific activities in the literature, or values that included certain fixed costs, such as shed construction and rent, not considered here (see Section 4.1). 'Mid-cost' estimates were thus sometimes at the lower or upper extreme of the quoted literature range, but were considered by these authors to be the most realistic costs. It is clear that there is a wide variation in cost estimates for some activities. Rabbit fencing may be required for SRCW if there are large rabbit populations in the area, and this is considered in the 'high' establishment cost estimate (Table 3). A high degree of certainty may be associated with establishment costs based on data from Rural Generation and the Miscanthus contractor [23], who base their 
Table 3 - Costs (adjusted to 2006 prices) associated with each of the activities outlined in Table 1, based on mid-cost estimates from the literature and maximum yields of 12 and $20 \mathrm{tha}^{-1} \mathrm{a}^{-1}$ for SRCW and Miscanthus, respectively

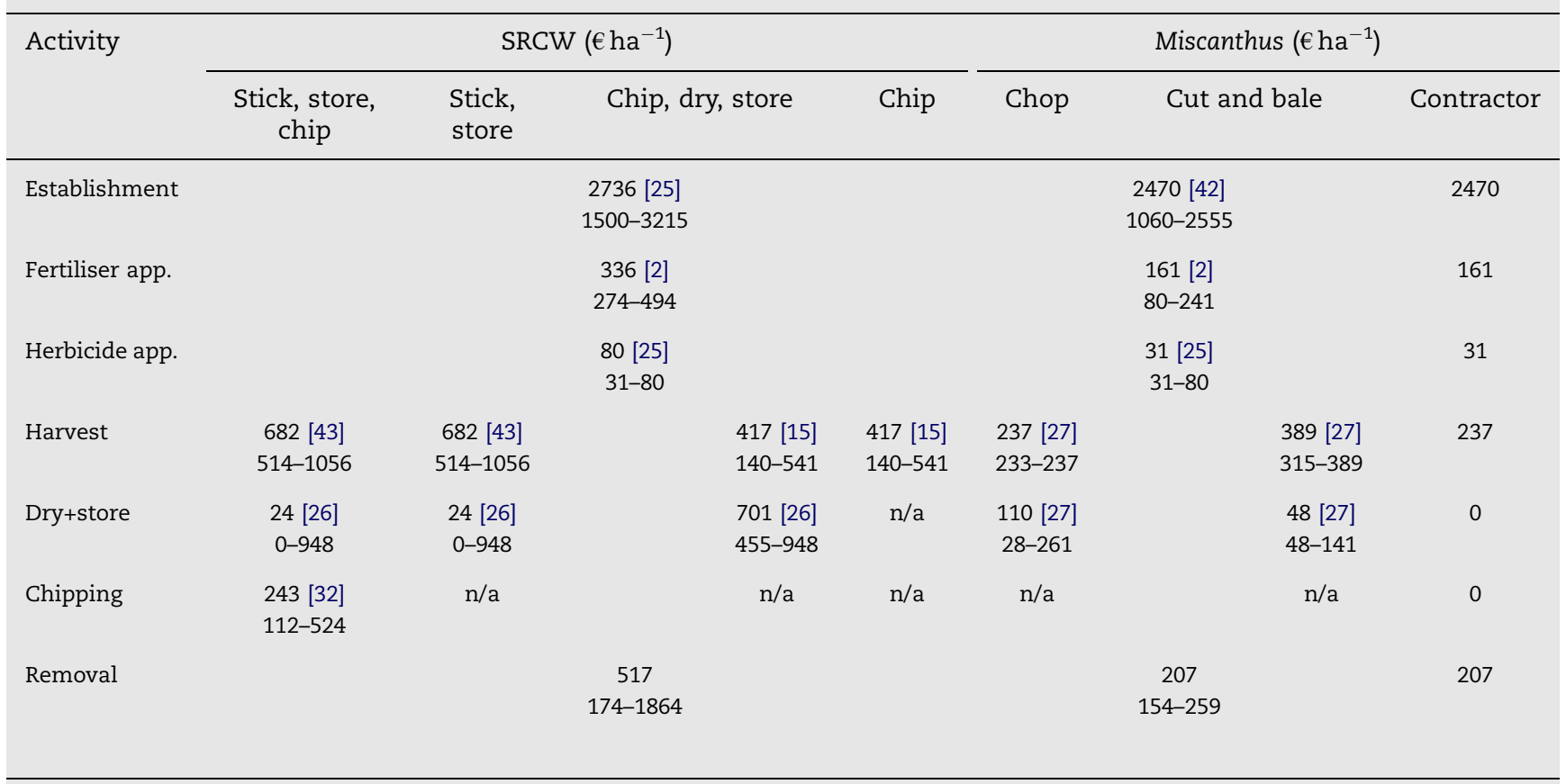

The ranges of low to high cost estimates from the literature are also displayed beneath. Miscanthus costs based on contractor establishment and immediate off-take are displayed on the right.

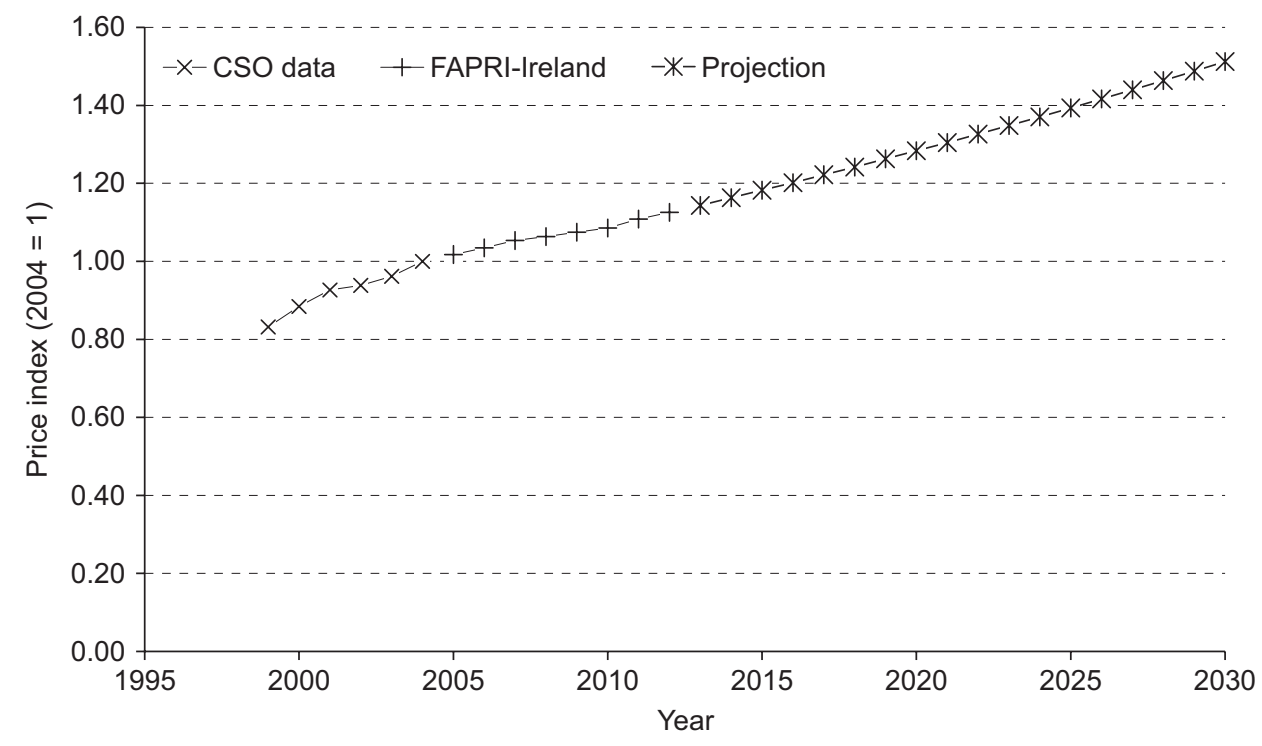

Fig. 1 - CSO, FAPRI-Ireland, and projected price inflation applied to model (Source: [2,6]). Projections based on 3-year rolling average extrapolated from FAPRI-Ireland data.

business practice on these costs. In fact, the Miscanthus establishment cost quoted by [23] is identical to (and perhaps based upon) the 2006-inflated DEFRA cost estimate. Fertiliser costs, based on average fertiliser prices quoted by [2], are also reliable. In contrast, drying and storage costs varied widely in the literature, depending on the techniques/equipment used and assumptions made in the cost calculations (discussed later), and these were associated with the greatest uncertainty. Fixed shed costs were not included in wood chip storage costs here, and outdoor storage of stick-harvested SRCW and Miscanthus under plastic sheeting was assumed [26], for an average of 9.5 months. ${ }^{1}$ Miscanthus storage costs of $€ 48$ and $€ 110 \mathrm{ha}^{-1} \mathrm{a}^{-1}$ for baled and chopped material [27], were high compared with SRCW storage costs of $€ 24 \mathrm{ha}^{-1} \mathrm{a}^{-1}$ [26], but this may be representative of higher yields and less

\footnotetext{
${ }^{1}$ Assume at least 6 months required to bring moisture content down to less than $20 \%$, based on [37].
} 
Table 4 - Low, mid and high annualised yield assumptions for SRCW and Miscanthus

\begin{tabular}{|c|c|c|c|c|}
\hline \multirow[t]{2}{*}{ Yield level } & \multicolumn{2}{|c|}{$\operatorname{SRCW}\left(\mathrm{tDM} h \mathrm{a}^{-1} \mathrm{a}^{-1}\right)$} & \multicolumn{2}{|c|}{ Miscanthus (tDM ha ${ }^{-1} \mathrm{a}^{-1}$ ) } \\
\hline & Standing & Combust. & Standing & Combust. \\
\hline \multicolumn{5}{|l|}{ Low } \\
\hline Av. 1st cut (s) & 4.0 & 3.4 & 9.3 & 6.5 \\
\hline Subsequent & 6.0 & 5.1 & 14.0 & 9.8 \\
\hline Plantation av. & 5.2 & 4.4 & 11.7 & 8.2 \\
\hline \multicolumn{5}{|l|}{ Mid } \\
\hline Av. 1st cut (s) & 8.0 & 6.8 & 13.3 & 9.3 \\
\hline Subsequent & 12.0 & 10.2 & 20.0 & 14.0 \\
\hline Plantation av. & 10.4 & 8.8 & 16.7 & 11.7 \\
\hline \multicolumn{5}{|l|}{ High } \\
\hline Av. 1st cut (s) & 9.3 & 7.9 & 17.3 & 12.1 \\
\hline Subsequent & 14.0 & 11.8 & 26.0 & 18.2 \\
\hline Plantation av. & 12.2 & 10.3 & 21.7 & 15.2 \\
\hline \multicolumn{5}{|c|}{$\begin{array}{l}\text { Yields are divided into those for the first cut (year 4) for SRCW and an average of the first } 2 \text { cuts (years } 2 \text { and 3) for Miscanthus, subseque } \\
\text { maximum annual yields, and plantation lifetime average. }\end{array}$} \\
\hline
\end{tabular}

favourable handling/storage properties of Miscanthus, so they were applied.

\subsection{Ex ante methods for comparing the economics of energy crops with traditional farming systems}

From the costs listed in Table 2, an economic spreadsheet model, based in Microsoft Excel, was used to evaluate the lifecycle economics of SRCW and Miscanthus. A net present value (NPV) approach was adopted, similar to that presented by [28], in which the two perennial energy crops considered were converted to an annual income stream, enabling a comparative economic analysis with competing conventional farming systems. Total costs and returns for the two energy crops over their 16 and 23 year plantation lifetimes were calculated as NPV for the year of plantation using a 5\% discount rate, annualised, and expressed per hectare. Where literature values were expressed per tDM they were converted to per hectare costs based on DM yield scenarios set out in Table 3. For Miscanthus, leaf senescence, harvest and storage losses were estimated at $30 \%$ of DM $[29,30]$, whilst for SRCW, harvest and storage losses were estimated at $15 \%$ (though this will vary according to harvest, drying and storage methods [26]). Within each cost level, the model varied fertiliser input, harvest, drying and storage costs in proportion to yield. A number of harvest and supply routes were considered-if energy crops are to continuously supply heat and power generation throughout the year, a range of harvest strategies may be required depending on the time period between harvest and combustion, and the method of combustion [26]. Unless otherwise stated, the main results presented are based on the 'mid-cost' estimates.

In the absence of well-defined markets for energy-biomass in Ireland, with only a pioneer market for wood fuels, the price farmers could expect to receive for energy crop biomass is uncertain, though likely to benefit from recent increases in energy costs. The Miscanthus contractor is offering a guaranteed price of approximately $€ 50 \mathrm{t}^{-1}$ of Miscanthus at up to $20 \%$ moisture content $\left(\sim € 63 \mathrm{t}^{-1} \mathrm{DM}\right)$, and this value is applied to the contractor scenario. Once a demand is established for biomass in Ireland (discussed later), prices may be expected to increase above this value. Here, we have assumed identical prices for Miscanthus and wood chips, at 70, 100 and $130 € \mathrm{t}^{-1} \mathrm{DM}$ for low, mid and high estimates. These prices are in line with the delivered price of moist wood chips quoted by Rural Generation in Northern Ireland ( $\left.€ 100 \mathrm{t}^{-1} \mathrm{DM}\right)$, and the current wood pellet price of approximately $€ 168 \mathrm{t}^{-1} \mathrm{DM}$ in the republic of Ireland [31], considering pellets contain $20 \mathrm{GJ} \mathrm{t}^{-1} \mathrm{DM}$ energy compared with $18 \mathrm{GJ} \mathrm{t}^{-1} \mathrm{DM}$ for wood chips at $20 \%$ moisture content, and their superior convenience. In the S2 supply strategy, where the farm-gate product is bundled sticks rather than chips, the price of the wood is reduced by $€ 5 \mathrm{t}^{-1} \mathrm{DM}$ over the price range considered (i.e. farm-gate prices of $€ 65$, $€ 95$ and $€ 125 \mathrm{t}^{-1} \mathrm{DM}$ ). This accounts for the additional cost of (more-efficient) centralised chipping incurred by the consumer (based on the 2006-adjusted prices of $€ 3.52 \mathrm{t}^{-1} \mathrm{DM}$ quoted by [26], and $€ 7.68 \mathrm{t}^{-1} \mathrm{DM}$ quoted by [32]). Similarly, in the C2 supply strategy, where wet chips are sold immediately after harvest, the price received for them is reduced by the additional transport cost ( €3.24 $\mathrm{t}^{-1} \mathrm{DM}$, over $\left.50 \mathrm{~km}\right)$ and according to their lower net heat of combustion. ${ }^{2}$ Thus, farm-gate prices of 60,87 and $115 € \mathrm{t}^{-1} \mathrm{DM}$ are applied to $\mathrm{C} 2$ supply strategy gross margin calculations. This was done in an effort to normalise farm-gate prices for SRCW, so that a standard product of chipped, dried (max $20 \%$ moisture content) wood was being compared among supply strategies.

Energy crop NPVs were compared with gross margins calculated for traditional farming systems in the republic of

\footnotetext{
${ }^{2}$ LHV of $16.4 \mathrm{GJ} \mathrm{t}^{-1} \mathrm{DM}$ at $50 \%$ MC compared with $18.1 \mathrm{GJ} \mathrm{t}^{-1} \mathrm{DM}$ at $20 \% \mathrm{MC}$ [35].
} 
Ireland; namely specialist dairy farms, specialist beef rearing farms, specialist other beef farms, and sugar beet, spring barley, winter wheat and set aside, as defined by the Teagasc National Farm Survey (NFS). The most up-to-date version of this survey [33] presents 2004 values, but gross margins have been extrapolated up to 2012 in the FAPRI-Ireland model $[7,34]$ based on predictions of the response to the new, decoupled subsidy scheme (Fig. 2). Unfortunately, farm-level FAPRI-projections for sheep farming could not be obtained, and this land use is therefore omitted from the comparison despite its probable high potential for substitution in Ireland. In 2005, there was a large decrease in gross margins associated with each agricultural system, reflecting the decoupling of subsidy payments from production (Fig. 2). The area-based SFP is activated simply by 'farming' the 2000-2002 reference land area in accordance with 'good environmental practises', and so would also be received by farmers growing energy crops. Therefore, this subsidy is not considered in the calculations here. However, the energycrop-specific EU subsidy of $€ 45 \mathrm{ha}^{-1} \mathrm{a}^{-1}$ is considered in the energy crop NPV, as it is activated only by growing energy crops. The CAP also enables farmers to sustain set-aside payments (though not the $€ 45 \mathrm{ha}^{-1} \mathrm{a}^{-1}$ subsidy) on set-aside land used for energy crops, so financial comparison of energy cropping with this land use excludes the energy crop subsidy and is based on the maintenance costs for set-aside land [7]. Gross margins in the NFS include labour costs, but not land rental or fixed farm costs. These costs are therefore not considered in the economic analyses of energy crops applied here, following the examples of $[14,16,17]$. The use of contractor prices for specialised operations such as planting and harvesting ensures that specialised machinery costs are indirectly accounted for.

In early 2007, the Irish Department for Agriculture and Food announced planting subsidies for SRCW and Miscanthus, to cover up to half of the establishment costs [19]. Planting on up to 1400 hectares is to be funded in 2007, and will be accompanied by an $€ 80 \mathrm{ha}^{-1} \mathrm{a}^{-1}$ energy-crop premium topup (bringing the total energy-crop premium to $€ 125 \mathrm{ha}^{-1} \mathrm{a}^{-1}$, except on set aside). The combined impact of these supports on discounted annual gross margins is included in NPV model runs for Miscanthus and SRCW, and the results presented alongside biomass-price sensitivity.

\section{Results}

\subsection{Production costs for different supply routes}

Fig. 3a displays the total, discounted annual production costs for each hectare of SRCW and Miscanthus, up to the farm gate, over plantation lifetimes of 23 and 16 years, respectively. Fig. $3 \mathrm{~b}$ displays the same costs expressed per $\mathrm{tDM}$ product. In both instances, total production costs for each supply route are broken down into major source categories. Discounted, annualised production costs for Miscanthus range from $€ 430$ to $€ 559 \mathrm{ha}^{-1}$, or, expressed per unit product, from $€ 37$ to $€ 48 \mathrm{t}^{-1} \mathrm{DM}$. These compare with annualised SRCW production costs ranging from $€ 275$ to $€ 407 \mathrm{ha}^{-1}$, or $€ 31$ to $€ 46 \mathrm{t}^{-1} \mathrm{DM}$. For Miscanthus, the B (baled) harvest strategy was slightly more expensive than the $C$ (chopped) harvest strategy (discounted costs of $€ 48$ compared with $€ 43 \mathrm{t}^{-1} \mathrm{DM}$ ), whilst the $\mathrm{A}$ (contractor) supply strategy (delayed, chopped harvest and immediate supply) was the least expensive at $€ 37 \mathrm{t}^{-1} \mathrm{DM}$. For SRCW production, the C1 (chip and dry) supply strategy was the most expensive, though only slightly more costly than the S1 (stick harvest and chip) supply strategy (discounted cost of $€ 46 \mathrm{t}^{-1} \mathrm{DM}$ ), and the C2 (wet-chip supply) strategy was the least expensive (discounted cost of $€ 32 \mathrm{t}^{-1} \mathrm{DM}$ ).

For SRCW supply strategies, establishment accounted for the largest portion of production costs $\left(€ 13 \mathrm{t}^{-1} \mathrm{DM}\right)$, whilst annual harvesting accounted for the largest portion of

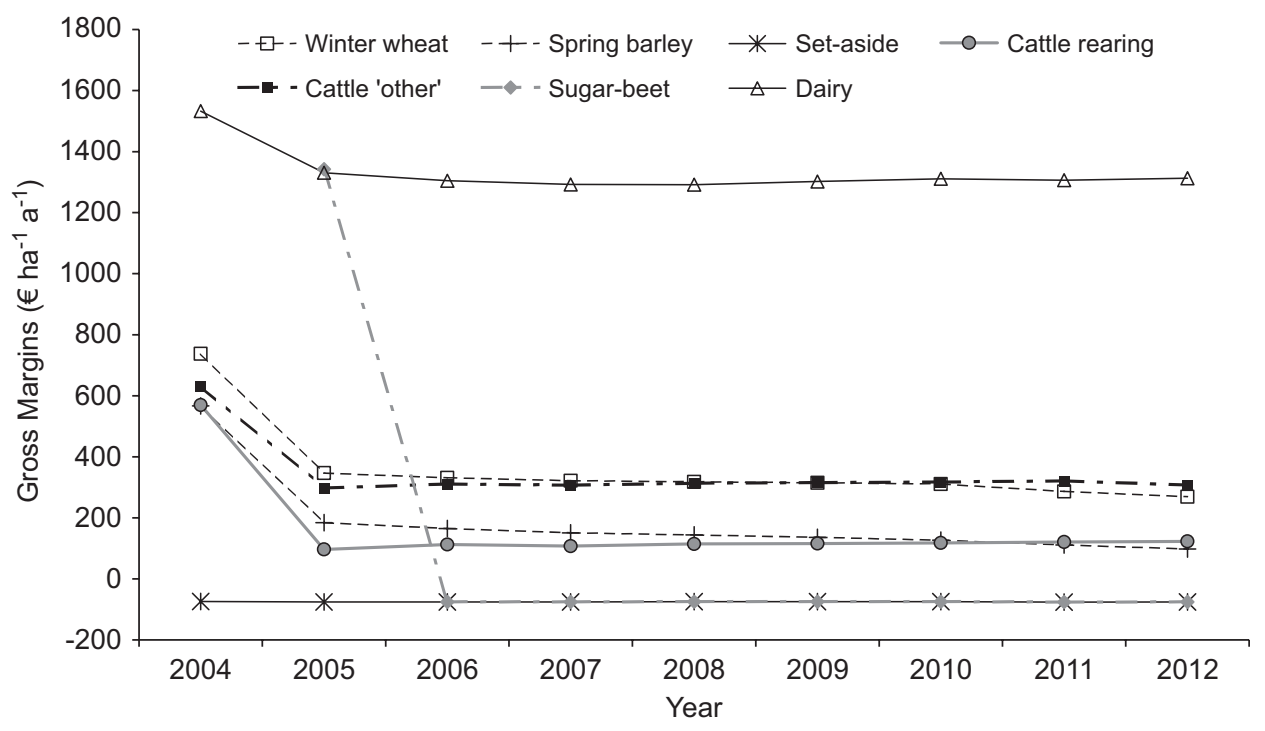

Fig. 2 - FAPRI-Ireland farm-level forecast gross margins for conventional systems, and the range of discounted annualised gross margins for energy crops for reference. 


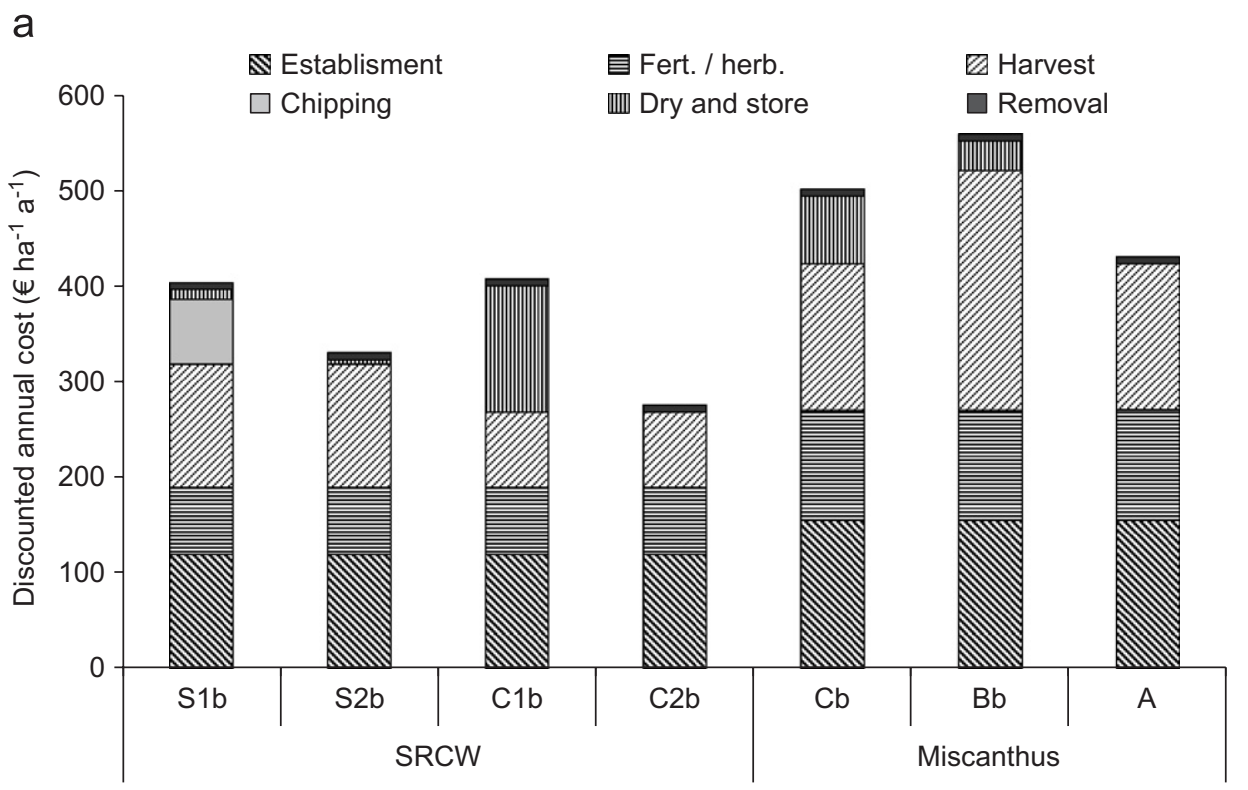

Harvest and supply route

b

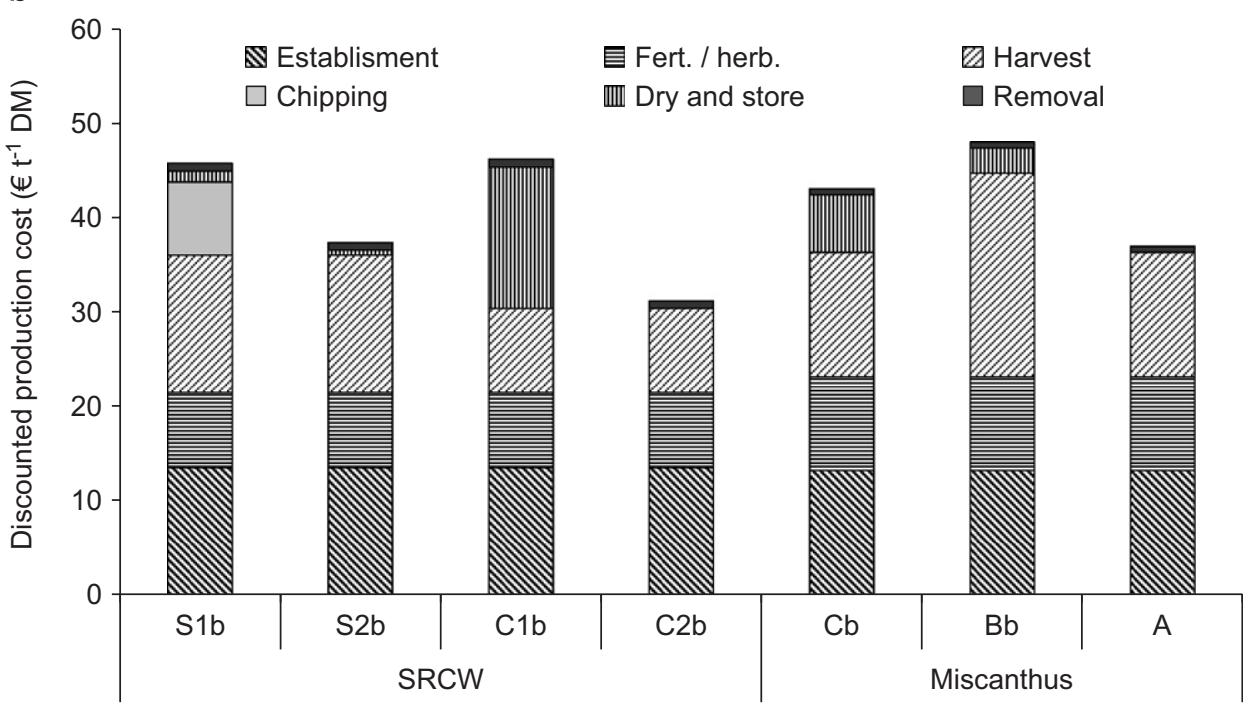

Harvest and supply route

Fig. 3 - 2006 production costs, expressed per hectare (a) and per tonne of combustible dry matter (b) for SRCW and Miscanthus broken down into main source categories.

Miscanthus production costs. Drying and storage incurred the largest cost in the case of the SRCW C1 supply strategy $\left(€ 15 \mathrm{t}^{-1} \mathrm{DM}\right)$, though incurred low costs for the other supply strategies. Fertiliser and herbicide application costs were significant, accounting for approximately one fifth of SRCW production costs $\left(€ 8 \mathrm{t}^{-1} \mathrm{DM}\right)$ and approximately one quarter of Miscanthus production costs $\left(€ 10 \mathrm{t}^{-1} \mathrm{DM}\right)$. After discounting and division over the crop lifetime, the cost of crop removal made a small contribution to overall costs.

\subsection{Energy crop gross margins and sensitivity analyses}

Table 5 displays annualised discounted profit margins for SRCW and Miscanthus, and variation of these margins in response to changed costs, yields and discount rates. Values are centred around mid-costs (Table 3), mid-yields (Table 4), a $5 \%$ discount rate, and a biomass price of $€ 100 \mathrm{t}^{-1} \mathrm{DM}$ (adjusted to 95 and $87 € \mathrm{t}^{-1} \mathrm{DM}$ for SRCW S2 and C2 strategies). These values vary according to low and high estimates for costs, presented in Table 3, yields presented in Table 4, and alternative discount rates of $3 \%$ and $8 \%$. Based on the midcost and mid-price estimates for energy crop production and sale, discounted, annualised gross margins from SRCW range from $€ 211 \mathrm{ha}^{-1} \mathrm{a}^{-1}$ for the C1 supply strategy to $€ 270 \mathrm{ha}^{-1} \mathrm{a}^{-1}$ for the C2 supply strategy (Table 5). For Miscanthus, gross margins are $€ 383$ and $€ 326 \mathrm{ha}^{-1} \mathrm{a}^{-1}$ for chopped and baled supply strategies, respectively (Table 5), and $€ 172 \mathrm{ha}^{-1} \mathrm{a}^{-1}$ in the instance of $€ 63 \mathrm{t}^{-1} \mathrm{DM}$ Quinn's price. 
Table 5 - Results of sensitivity analyses, comparing discounted, annualised profit margins (2006 prices) at different cost levels, yields and discount rates

\begin{tabular}{|c|c|c|c|c|c|c|}
\hline & \multicolumn{4}{|c|}{$\operatorname{SRCW}\left(€ h \mathrm{a}^{-1} \mathrm{a}^{-1}\right)$} & \multicolumn{2}{|c|}{ Miscanthus $\left(€ \mathrm{ha}^{-1} \mathrm{a}^{-1}\right)$} \\
\hline & S1 & S2 & $\mathrm{C} 1$ & $\mathrm{C} 2$ & C & B \\
\hline \multicolumn{7}{|l|}{ Cost } \\
\hline Low & 373 & 364 & 385 & 397 & 586 & 519 \\
\hline Mid & 245 & 261 & 211 & 270 & 383 & 326 \\
\hline High & -139 & -71 & 59 & 166 & 103 & -13 \\
\hline \multicolumn{7}{|l|}{ Yield } \\
\hline Low & 32 & 44 & 19 & 49 & 270 & 230 \\
\hline Mid & 245 & 261 & 211 & 270 & 383 & 326 \\
\hline High & 296 & 314 & 257 & 324 & 609 & 535 \\
\hline \multicolumn{7}{|c|}{ Discount rate } \\
\hline $3 \%$ & 294 & 314 & 251 & 325 & 472 & 405 \\
\hline $5 \%$ & 245 & 261 & 211 & 270 & 383 & 326 \\
\hline $8 \%$ & 128 & 139 & 102 & 146 & 279 & 232 \\
\hline
\end{tabular}

Applying the low cost estimates results in substantially higher discounted annual gross margins, of up to $€ 397$ and $€ 586 \mathrm{ha}^{-1} \mathrm{a}^{-1}$ for SRCW (C2a) and Miscanthus (Ca), respectively. Conversely, applying the high cost estimates diminishes discounted annual gross margins, down to $-€ 139$ and $-€ 13 \mathrm{ha}^{-1} \mathrm{a}^{-1}$ for SRCW (S1c) and Miscanthus (Bc), respectively. Positive gross margins were maintained assuming combustible yield reductions of $50 \%$ and $30 \%$ for SRCW and Miscanthus, but were reduced by up to 91\% (SRCW-C1) and $30 \%$ (Miscanthus-C), respectively (Table 5). The assumption of yield increases of $17 \%$ and $30 \%$ for SRCW and Miscanthus resulted in gross margin increases of up to $22 \%$ (SRCW-C1) and 64\% (Miscanthus-B), respectively (Table 5). Discounted Miscanthus gross margins exceeded $€ 600 \mathrm{ha}^{-1} \mathrm{a}^{-1}$ under the high-yield scenario. Gross margins proved less sensitive to variation in discount rates than to variation in costs and yields. Reducing the discount rate applied from 5\% to 3\% increased discounted annual per hectare gross margins to between $€ 251$ (39\% increase) and $€ 325$ (20\% increase) for SRCW, and to $€ 405$ ( $24 \%$ increase) and $€ 472$ ( $18 \%$ increase) for Miscanthus. Increasing the discount rate applied from $5 \%$ to $8 \%$ reduced discounted annual per hectare gross margins to between $€ 102$ (43\% decrease) and $€ 146$ (46\% decrease) for SRCW, and to $€ 232$ (29\% decrease) and $€ 279$ (27\% decrease) for Miscanthus (Table 5).

Discounted annual gross margins were highly sensitive to variation in the energy crop biomass price from 70 to 130 $€ \mathrm{t}^{-1} \mathrm{DM}$ (Table 6). At a $€ 70 \mathrm{t}^{-1} \mathrm{DM}$ price, SRCW gross margins were reduced to between 33 and $110 € \mathrm{ha}^{-1} \mathrm{a}^{-1}$, and Miscanthus gross margins to 109 and $167 € \mathrm{ha}^{-1} \mathrm{a}^{-1}$. At a $€ 130 \mathrm{t}^{-1} \mathrm{DM}$ price, SRCW gross margins were increased to between 388 and $436 € \mathrm{ha}^{-1} \mathrm{a}^{-1}$, and Miscanthus gross margins to 651 and $708 € \mathrm{ha}^{-1} \mathrm{a}^{-1}$. Incorporating the new $50 \%$ establishment grant (up to $€ 1450 \mathrm{ha}^{-1}$ ) and $€ 80 \mathrm{ha}^{-1} \mathrm{a}^{-1}$ energycrop premium top-up would result in substantial increases for energy-crop gross margins. The impact is especially great for low farm-gate biomass prices, where gross-margins are increased by between $105 \%$ and $352 \%$ for SRCW, and by between $87 \%$ and $132 \%$ for Miscanthus. At mid- and highbiomass prices, these subsidies would have a proportionately smaller, but significant, overall effect on discounted annual gross margins. For example, they would increase mid-price gross margins for SRCW by between $43 \%$ and $55 \%$, and for Miscanthus by $38 \%$ and $44 \%$, enabling healthy mid-price discounted gross margins of up to 386 and $527 € \mathrm{ha}^{-1} \mathrm{a}^{-1}$ for SRCW and Miscanthus, respectively (Table 6).

\subsection{Waste-water treatment}

There is an increasing realisation of the potential to utilise SRCW for biofiltration treatment of wastes and contaminated land, owing to the dense root network and high transpiration rate of willow. Bjorsson [36], and Rosenqvist and Dawson [18], estimated the waste-water treatment capacity of SRCW and attributed values to this, in the contexts of Sweden and Northern Ireland respectively. Figures from [18] were applied here, with the assumption that circumstances should be similar between the North and Republic of Ireland. Their figures comprised an estimated annual cost of $€ 1306 \mathrm{ha}^{-1}$ for capital investment in irrigation ponds, pumps, pipes, pumping costs, labour, etc., and a $100 \%$ reduction in fertiliser costs. The potential net annual income from waste-water treatment, assuming full payment of the conventional treatment cost, was estimated at between $€ 1159$ and $€ 2947 \mathrm{ha}^{-1}$ depending on conventional treatment method. Here, the mid-point value of $€ 2053 \mathrm{ha}^{-1} \mathrm{a}^{-1}$ was used as an estimate of farm revenue from WW treatment, resulting in a net income of $€ 747 \mathrm{ha}^{-1} \mathrm{a}^{-1}$, before discounting. Table 6 displays discounted, annualised gross margins for the range of energycrop biomass price scenarios, for mid-yield estimates, when WW treatment returns are applied. Assuming a biomass price of $€ 100 \mathrm{t}^{-1} \mathrm{DM}$, WW treatment could raise gross margins substantially to between $€ 774$ and $€ 833$ per hectare per year for SRCW. 
Table 6 - The impact of varying farm-gate energy crop biomass prices $\left(70,100\right.$ and $\left.130 € t^{-1} \mathrm{DM}\right)$, use of SRCW for wastewater treatment, and recently announced $50 \%$ establishment subsidy with $680 \mathrm{ha}^{-1} \mathrm{a}^{-1}$ top-up payment, on discounted, annualised gross margins for different energy crop strategies

\begin{tabular}{|c|c|c|c|c|c|c|}
\hline \multirow[t]{2}{*}{ Price $\left(€ \mathrm{t}^{-1} \mathrm{DM}\right)$} & \multicolumn{4}{|c|}{$\operatorname{SRCW}\left(€ \mathrm{ha}^{-1} \mathrm{a}^{-1}\right)$} & \multicolumn{2}{|c|}{ Miscanthus $\left(€ \mathrm{ha}^{-1} \mathrm{a}^{-1}\right)$} \\
\hline & S1 & $\mathrm{S} 2$ & C1 & $\mathrm{C} 2$ & C & B \\
\hline \multicolumn{7}{|l|}{ Biomass } \\
\hline 70 & 68 & 84 & 33 & 110 & 167 & 109 \\
\hline 100 & 245 & 261 & 211 & 270 & 383 & 326 \\
\hline 130 & 423 & 439 & 388 & 436 & 708 & 651 \\
\hline \multicolumn{7}{|c|}{ Biomass+WW treatment } \\
\hline 70 & 631 & 647 & 596 & 673 & & \\
\hline 100 & 808 & 824 & 774 & 833 & & \\
\hline 130 & 986 & 1002 & 951 & 999 & & \\
\hline \multicolumn{7}{|c|}{ Subsidy (50\% est.+€80 $\left.a^{-1}\right)$} \\
\hline 70 & 184 & 200 & 149 & 226 & 311 & 254 \\
\hline 100 & 362 & 377 & 327 & 386 & 527 & 470 \\
\hline
\end{tabular}

\subsection{Comparison with conventional agricultural crops}

Fig. 2 displays the data from the farm-level FAPRI projections for selected conventional agricultural systems, extrapolated from 2004 data, and running until 2012. Most of the conventional agricultural systems exhibit a sharp decline in gross margins between 2004 and 2005, after which they remain relatively stable through to 2012, reflecting the decoupling of subsidy payments from production (and thus exclusion from gross margin calculations) in 2005. Sugar-beet gross margins decline steeply from a high 2005 value of $€ 1342 \mathrm{ha}^{-1} \mathrm{a}^{-1}$ to the equivalent of set-side payments in 2006 , reflecting the recent announcement that the only sugar processing factory in Ireland is to close. On the other hand, high initial dairy gross margins remain fairly steady at over $€ 1300 \mathrm{ha}^{-1} \mathrm{a}^{-1}$ through to 2012.

Fig. 4 compares annualised, discounted (mid-estimate) gross margins for the different conventional agricultural land uses and energy cropping strategies, calculated over the 16 and 23 year timescales of Miscanthus and SRCW cultivation, respectively. Both the Miscanthus C and B supply strategies prove highly competitive with all but the dairy $\left(€ 965 \mathrm{ha}^{-1} \mathrm{a}^{-1}\right)$ land uses, whilst the Miscanthus A strategy fails to match the gross margins for 'cattle and other' $\left(€ 229 \mathrm{ha}^{-1} \mathrm{a}^{-1}\right)$ or winter wheat $\left(€ 214 \mathrm{ha}^{-1} \mathrm{a}^{-1}\right)$ land use classifications, but is competitive with spring barley $\left(€ 87 \mathrm{ha}^{-1} \mathrm{a}^{-1}\right)$, sugar beet $\left(-€ 56 \mathrm{ha}^{-1} \mathrm{a}^{-1}\right)$, set aside $\left(-€ 56 \mathrm{ha}^{-1} \mathrm{a}^{-1}\right)$ and cattle rearing $\left(€ 88 \mathrm{ha}^{-1} \mathrm{a}^{-1}\right)$. All but the C1 SRCW strategies proved competitive with all the land use classifications except dairy $\left(€ 867 \mathrm{ha}^{-1} \mathrm{a}^{-1}\right)$. Removing the $€ 45 \mathrm{ha}^{-1} \mathrm{a}^{-1}$ subsidy has a small impact on energy crop returns, reducing discounted gross margins for Miscanthus by approximately $€ 35 \mathrm{ha}^{-1} \mathrm{a}^{-1}$, and for SRCW by approximately $€ 31 \mathrm{ha}^{-1} \mathrm{a}^{-1}$. Therefore, all energy crop production and supply strategies return gross margins considerably higher than set aside (Fig. 4). The annualised, discounted gross margin resulting from including WW treatment in combination with the mid-range SRCW-S1 strategy ( $\left.€ 808 \mathrm{ha}^{-1} \mathrm{a}^{-1}\right)$ proved highly competitive with all land uses, and was only $10 \%$ below the average dairy gross margin. Similarly, including the recently-announced energycrop establishment grant and subsidies significantly elevated energy-crop gross margins compared with most conventional land uses (Fig. 4). This was especially true for the SRCW C2, wet-chip supply strategy, reflecting the lower overheads for this strategy (Fig. 3). For simplicity, these comparisons were made for mid-estimate energy-crop gross margins only. Varying the yield, biomass price and activity-cost estimates (Tables 5 and 6) would substantially alter these comparisons.

\section{Discussion}

\subsection{Energy crop production costs}

The least certain cost estimates are those for storage and drying. These largely depend on the techniques used, but the range of values in the literature also reflects different methods of calculation. If the shed storage cost of $€ 2.77 \mathrm{t}^{-1} \mathrm{DM}$ month ${ }^{-1}$ calculated in [26] was applied in this study, wood chip production would increase in cost by approximately $€ 284 \mathrm{ha}^{-1} \mathrm{a}^{-1}$ (assuming 9.5 months average storage). Such fixed costs are not directly considered in the FAPRI-Ireland model projections, or energy crop cost calculations in this study, although machinery costs are indirectly accounted for through contractor costs for planting, maintenance and harvest operations. Flexible harvest timing for SRCW offers the possibility to plan harvesting around storage availability, and [14] ignored fixed costs associated with SRCW production on the assumption that only $10-15 \%$ of any farm's land would be converted to SRCW cropping, ensuring that existing facilities would be adequate. For stick-harvested SRCW, and Miscanthus, 6 months of outside storage may reduce moisture content to less than $15 \%$ [30,37]. In this study, a final moisture content of $20 \%$ or less was assumed after 
a

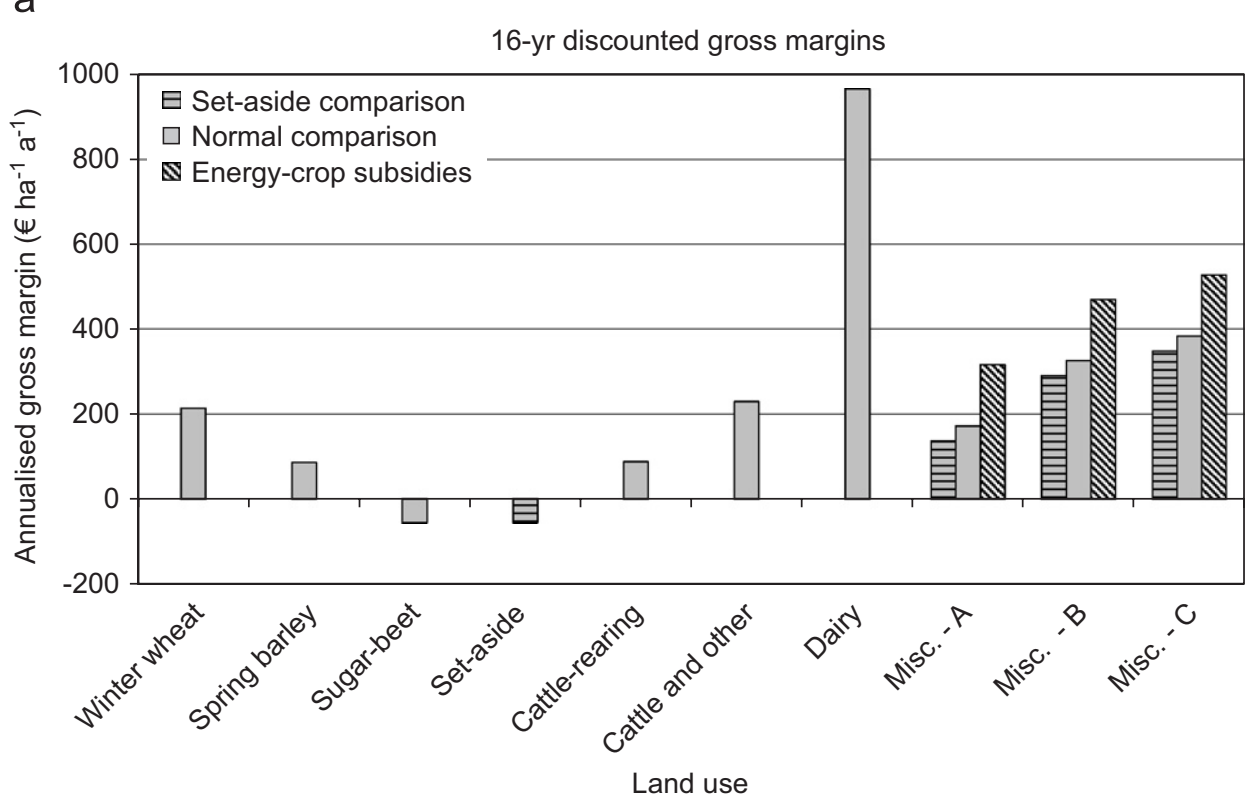

b

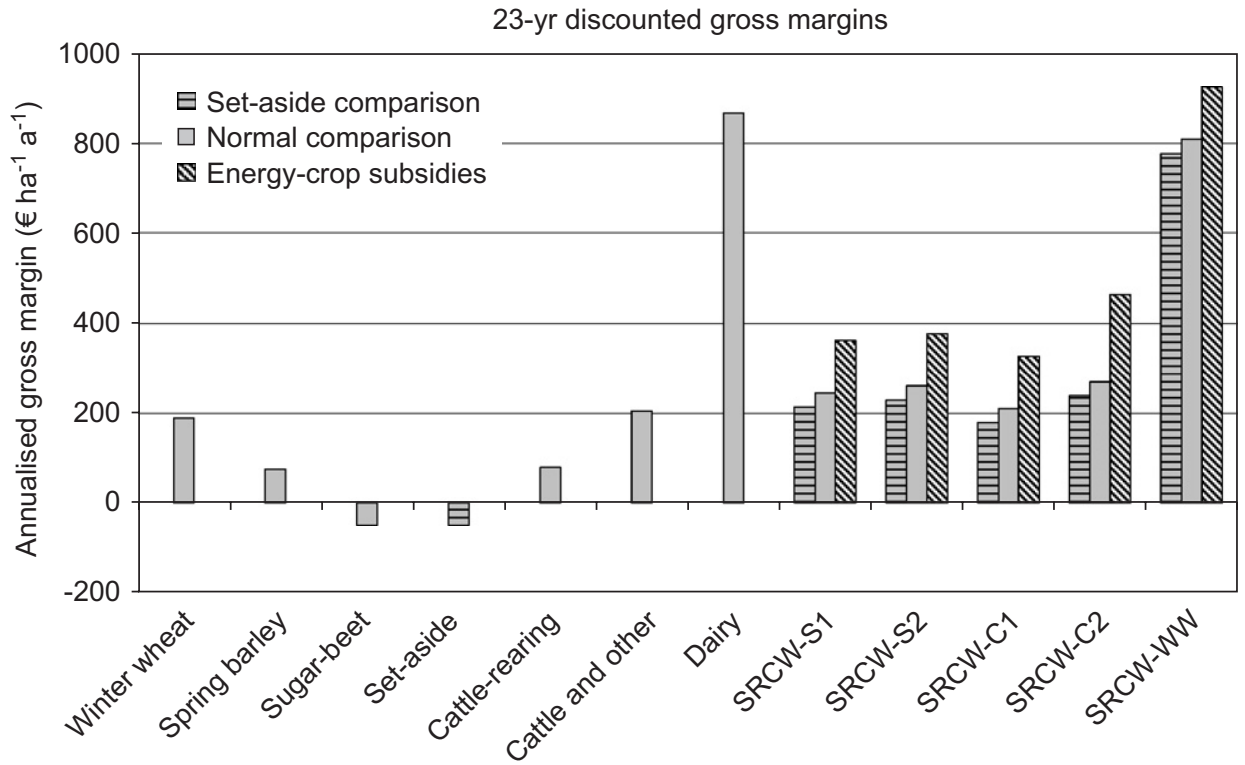

Land use

Fig. 4 - Discounted, annualised gross margins for conventional agricultural systems and energy crop plantations over the 16 (a) and 23 (b) year plantation lifetimes of Miscanthus and SRCW. Comparisons with set aside (minus $€ 45$ ha $^{-1} \mathrm{a}^{-1}$ energy crop subsidy), without, and with, additional subsidies, respectively.

outdoor storage under plastic sheeting, at relatively low costs (Table 3). Harvesting SRCW as chips requires the forced drying of wood chips prior to storage, unless moist chips are to be used immediately (e.g. in gasification boilers or large combustion plants) or cheaply dried by the consumer (e.g. using waste process-heat). Forced ventilation drying of wood chips with heated air is expensive, and was calculated to cost between $€ 14$ and $€ 29 \mathrm{t}^{-1} \mathrm{DM}$ by [38]. Rabbit fencing was not accounted for in the 'mid-cost' estimates, though this cost will only be incurred if there are significant rabbit populations in the area, and will ultimately be highly dependent on the size of the plot. Increasing establishment costs by $€ 500 \mathrm{ha}^{-1}$ to account for rabbit fencing would result in discounted, annualised gross margins decreasing by approximately $€ 22 \mathrm{ha}^{-1} \mathrm{a}^{-1}(<10 \%)$.

Higher costs of production per hectare for Miscanthus compared with SRCW reflect the higher fertiliser requirements, annual (compared with 3-yearly) harvesting requirement, and shorter plantation time over which establishment costs are divided for Miscanthus. However, these higher costs are compensated for by higher yields, and discounted production costs per tonne of DM (Fig. 2) are similar for SRCW (€32-€47) and Miscanthus (€36-€47). In fact, non-discounted, price-inflated costs per tonne of DM are 
higher for SRCW (€56-€83 $\left.\mathrm{t}^{-1} \mathrm{DM}\right)$ than for Miscanthus $\left(€ 52-€ 67 \mathrm{t}^{-1} \mathrm{DM}\right)$, reflecting the longer discount and priceinflation period used in SRCW calculations (23 compared with 16 years). Sensitivity analyses indicated that the cost of SRCW production was more susceptible to variation in yield and discount rate than Miscanthus, reflecting the higher portion of costs (fertiliser application, annual harvest and storage) linked directly with yield, and the shorter crop lifetime, in the instance of Miscanthus. The cost of dried wood chip production quoted by [39] $\left(€ 50 \mathrm{t}^{-1} \mathrm{DM}\right)$ lies between the discounted and non-discounted price-inflated costs of dried wood chip production calculated here.

\subsection{Supply strategies}

It is apparent that the harvest and supply strategy has a critical impact on production costs, and on additional transport, handling and preparation costs that may be borne by either the producer or consumer. Combined harvest and chipping is cheaper than stick harvest ( $€ 417$ compared with $€ 682 \mathrm{ha}^{-1}$ ), and saves substantial post-harvest chipping costs of $€ 226 \mathrm{ha}^{-1}$ (decentralised), or $€ 106$ (centralised), for the farmer. If SRCW is to be used as a feed stock for peat power stations, adequate size-reduction may be achieved through chunking, rather than chipping, with decentralised costs of $€ 86 \mathrm{ha}^{-1}$ (based on [26]). Unless chips are immediately used, they incur substantial drying costs of $€ 701 \mathrm{ha}^{-1}$ [26] and will require shed storage space, compared with cheap outdoor stick storage. The lower density of Miscanthus enables natural drying of both baled ${ }^{3}$ and chopped material [30]. Higher costs for baled harvest compared with chopped harvest (€389 vs $€ 287 \mathrm{ha}^{-1}$ ) are partially offset by lower storage costs for baled material ( $€ 48$ vs $110 \mathrm{ha}^{-1}$ ), and may also result in higher combustible yields through collection of senesced leaf material (though this would also increase nutrient uptake and deteriorate combustion properties). Transport of the baled material may also be cheaper, though this should be considered against any necessary disaggregation and chopping costs incurred prior to combustion. Non-adjusted transport and handling costs calculated by [27] of 6.8 and $8.9 € \mathrm{t}^{-1}$ over $20 \mathrm{~km}$ for baled and chopped Miscanthus, respectively, are considerably higher than biomass transport costs of $€ 4.1 \mathrm{t}^{-1}$ for $50 \mathrm{~km}$ calculated for Ireland by [5]. Such costs are difficult to accurately quantify in the absence of national case-studies.

Here, variable costs incurred by the consumer according to the supply strategy are reflected in variable biomass prices: i.e. the chipping costs for supply of stick bundles, and the additional transport costs and reduced LHV of wet wood chips, are translated into reduced biomass prices received for these products. This standardises the product output to an equivalent of chipped, dried (maximum 20\% MC) wood chips for SRCW, but has the effect of reducing the impact of supplystrategy on gross margins for farmers. If additional processing costs were borne by the consumer, farmers could realise substantially higher profits. For example, applying the standard farm-gate price of $€ 100 \mathrm{t}^{-1} \mathrm{DM}$ to wet wood chip in the NPV model (instead of the adjusted $€ 87 \mathrm{t}^{-1} \mathrm{DM}$ ), results in

\footnotetext{
${ }^{3}$ Assuming moisture reduction prior to late winter harvest.
}

the $\mathrm{C} 2$ production strategy realising discounted gross margins of $€ 347$ (rather than $€ 270$ ) ha $\mathrm{a}^{-1} \mathrm{a}^{-1}$. Ultimately, there will be a need for coordination along the supply-consumer chain, and this may optimise cost-sharing between producers and consumers. For example, some large consumers may be able to cost-effectively dry wood chip utilising waste heat (with associated energy-balance benefits compared with forced drying). The lowest-cost supply strategy depends on a number of factors, including moisture content at harvest, the time between harvest and combustion, the method of energy conversion, the possibility to utilise waste heat in drying [26]. Further work is needed to explore the logistics and feasibility of possible energy-cop supply to consumer chains within Ireland, with the aim of optimising the energy balance and economics. The farm-gate biomass prices applied in this paper, for chipped/chopped biomass at $20 \%$ moisture content, are used as the input to energy-crop electricity and heat production in a related paper [12].

\subsection{Prices and market establishment}

The farm-gate price range of 70,100 and $130 € \mathrm{t}^{-1} \mathrm{DM}$ applied here for indicative purposes is based around current actual prices in Ireland's fledgling wood-fuel market. In N. Ireland, Rural Generation is delivering wood chips for around $€ 100 \mathrm{t}^{-1} \mathrm{DM}$ [39], and wood pellets are sold for prices of $€ 168 \mathrm{t}^{-1} \mathrm{DM}$ in bulk, and up to $€ 333 \mathrm{t}^{-1} \mathrm{DM}$ by the bag [31]. Pellets will command significantly higher prices than wood chips due to their higher energy content $\left(20.0 \mathrm{GJ} \mathrm{t}^{-1} \mathrm{DM}\right.$ compared with $18.1 \mathrm{GJ} \mathrm{t}^{-1} \mathrm{DM}$ ) and superior handling and combustion properties. Irish wood chip prices are high compared with some wood chip price estimates used elsewhere, such as the $€ 40$ and $€ 59 \mathrm{t}^{-1} \mathrm{DM}^{4}$ used by [16] to calculate the economics of willow production in Poland. However, those same authors refer to a wide range of wood chip prices in Europe, citing examples ranging from $€ 47 \mathrm{t}^{-1} \mathrm{DM}^{4}$ in Germany to $€ 94 \mathrm{t}^{-1} \mathrm{DM}^{4}$ in Denmark. Miscanthus prices are more speculative, as no market exists for Miscanthus yet in Ireland. It is assumed that ultimately energy producers may be willing to pay the same price for Miscanthus as for wood chip once a market is established, but initially farmers can only expect the farm-gate price of $€ 63 \mathrm{t}^{-1} \mathrm{DM}$ offered by the contractors (although presumably this is less than the end consumer is willing to pay). Whilst farmers could maximise farm-gate prices through direct supply to final consumers, intermediaries may prove necessary to hedge some of the risk involved and guarantee contracts for both farmers and consumers. Additionally, as indicated by [17], initial small-scale 'pioneer grower' costs could prove to be higher than cost estimates used here as techniques are adapted to, though this effect could be reduced if contractors are used. It is therefore possible that initial returns for pioneer farmers may be closer to those based on the lower price estimate of $€ 70 \mathrm{t}^{-1} \mathrm{DM}$.

There are signs that momentum is building in the Irish biomass-fuel market, with positive implications for future

\footnotetext{
${ }^{4}$ Converted from 2003 price expressed per MWh fuel to 2006 price expressed per tDM, based on $5 \mathrm{MWh}(18 \mathrm{GJ}) \mathrm{t}^{-1} \mathrm{DM}$ lower heating value and inflation values in Fig. 1.
} 
energy-crop biomass prices. In recent years, a small number of wood chip suppliers have begun operating in Ireland, and the relatively new Edenderry peat power-station ${ }^{5}$ has recently been taken over by Ireland's peat supply board (Board nà Mona) with the intention of experimentation with alternative biomass fuels. After adding transport costs and tax to the farm-gate prices used in this study, Miscanthus and SRCW were calculated to be borderline competitive as fuel for electricity generation compared with peat through co-firing, and highly competitive as a source of heat generation in domestic boilers (even at a farm-gate price of $€ 130 \mathrm{t}^{-1} \mathrm{DM}$ ) [12]. Upward pressure on energy prices through fossil fuel and $\mathrm{CO}_{2}$ emission costs may result in large-scale energy producers willing to pay more for biomass fuels in the future, towards the speculative upper price level of $€ 130 \mathrm{t}^{-1} \mathrm{DM}$ used here. Rosenqvist and Dawson [17] report that market development in Sweden resulted in a decline in wood chip prices to around $€ 57 \mathrm{t}^{-1} \mathrm{DM}(\sim 2003)$ as a consequence of abundant supply from vast forests and large areas of efficient SRCW cultivation. The availability of competing wood sources in Ireland is far lower than in Sweden, with less than $10 \%$ of Ireland's national land area forested, compared with $70 \%$ under agricultural uses. Utilisation of alternative biomass supplies, such as meat and bonemeal and forestry thinnings, is likely in Ireland, though whether this dampens or primes the market for energy-crop biomass will depend on the scale of future demand for biomass.

The recently announced establishment and annual subsidy top-up payments for Miscanthus and SRCW cultivation in Ireland [19] significantly improve NPV calculations for energycrop plantations, and extend the benefit of energy crops compared with most of the conventional agricultural systems referred to in this study. These payments offer good insurance against gross revenues being diminished by high costs and low yields, and generate a high probability that energy-crop gross margins will be favourable compared with alternative land uses. However, the greatest impact is likely to be the reduced risk and shorter payback period associated with the $50 \%$ establishment grant (two-thirds paid in the establishment year, one third in the subsequent year). Worth up to $€ 1450 \mathrm{ha}^{-1}$, this grant substantially reduces the high initial outlay (2736 and $2470 € \mathrm{ha}^{-1}$ for SRCW and Miscanthus, respectively) required from farmers to cultivate these energy crops, and thus reduces the risk-based inertia and payback commitment period.

\subsection{Competitiveness with conventional crops}

The decoupling of subsidy payments from production in January 2005 substantially decreased gross margins attributable to conventional agricultural production, although dairy gross margins remain relatively high. The proposed reform of the EU common market organisation for sugar, and the decision by Irish Sugar to cease processing sugar in 2006,

\footnotetext{
${ }^{5}$ A modern circulating fluidised bed boiler design capable of co-firing high proportions of biomass alongside peat with no major modifications. Two similar power stations have recently commenced electricity generation, bringing total peat power station capacity to $375 \mathrm{MW}_{\mathrm{e}}$.
}

reduces the market based gross margin for sugar beet to levels equivalent to that of set-side land. In combination with the modest EU biofuel subsidy of $€ 45 \mathrm{ha}^{-1} \mathrm{a}^{-1}$, and recently announced Irish-specific subsidies (for a restricted number of farmers), these factors present a strong opportunity for energy crops, such as Miscanthus and SRCW, to compete financially with existing agricultural land uses. When all possible land uses are compared as a stream of future net revenue over the plantation lifetimes of Miscanthus and SRCW using the NPV method, annualised returns for these crops prove to be highly competitive with a number of the major current agricultural land uses. In particular, future gross margins predicted for sugar beet, spring barley and cattle rearing are low, and uncompetitive with any of the energy cropping strategies considered here. The most profitable energy-cropping strategies (i.e. SRCW-C2 and Miscanthus C) are competitive with all the other land uses considered, except dairy. Well-managed, and planted on good-quality soils, the high DM yields attainable from these energy crops offer relatively high earning potential for farmers compared with current options. Planting on set-aside land is financially an attractive option, but would disrupt current crop rotation systems and may cause some logistical difficulties. Opportunities for multiple uses, such as WW and sewage sludge treatment, further enhance the financial attractiveness of SRCW, and could substantially increase farm revenues.

In addition to biomass price assumptions discussed earlier, calculated returns from energy crops were based on mid-yield and mid-cost estimates, and a discount rate of $5 \%$. Low yields could render SRCW uncompetitive with average gross margins for productive agricultural land uses, although Miscanthus remains competitive due to lower yield-related costs (Table 5). If these low yields are caused by poor growing conditions, presumably conventional agricultural productivity would also be impaired, and comparative gross margins would be lower. This may prove to be an advantage for SRCW, which does comparatively well in wet conditions [40]. The greatest potential threat to energy crop gross margins is variation in cultivation costs. The high-cost estimates used in the sensitivity analyses applied here result in negative returns for some energy crop harvest and supply strategies (Table 5). These are highly pessimistic estimates, however, incorporating the highest costs found in the literature for all activities, and include high fixed costs not included in the compared conventional land use gross margins. With respect to the impact of biomass pricing, even at the lower biomass price of $€ 70 \mathrm{t}^{-1} \mathrm{DM}$, returns would be competitive with cattle rearing and spring barley, not to mention set aside and sugar beet. Generally, the annual harvest and higher proportion of yield-related costs make Miscanthus less susceptible to variations in the parameters applied to the economic model.

\subsection{Barriers and opportunities}

The main barriers to realising potential energy crop profits are market uncertainty combined with the risk of large upfront establishment costs. Farmers are reluctant to invest into such 
long-term financial commitments as SRCW and Miscanthus plantations before a developed market for biomass emerges. Conversely, potential consumers (householders, building managers, electricity generators) are reluctant to invest in the technology necessary for energy crop utilisation before guaranteed biomass supplies become established. These supplies may initially be dominated by non-energy-crop biomass. There are positive signs of change, in the form of the recently announced Miscanthus and SRCW establishment subsidies, and significant consumer subsidies for wood heat (up to $€ 4200$ to householders investing in wood boilers and stoves). However, the ongoing challenge will be to coordinate planning of supply strategies between potential consumers and farmers, and to integrate policy between relevant government departments. As indicated elsewhere (e.g. [26]), it is clear that overall supply-chain costs could be reduced through coordinated, logistical planning of supply and utilisation networks.

The higher yields, higher potential profits, shorter period to first harvest, greater similarity with existing cropping practices, and the potential to apply existing farm machinery and techniques, may favour Miscanthus over SRCW from a farmer perspective. However, SRCW may be grown on wetter, less agriculturally productive (less profitable) soils, and offers the opportunity to generate extra revenue through WW treatment. Wood chip is also a more suitable fuel than Miscanthus for small-scale heating boilers (Miscanthus would need to be pelleted, with associated logistical and financial complications). Initial Miscanthus utilisation is most likely to occur via co-firing in peat power stations, but broader utilisation could be achieved through research and development into utilisation in smaller boilers (e.g. assessing the feasibility of pelleting), or following gasification or lignocellulosic digestion to produce gaseous/liquid fuels. Further research and development could identify optimum utilisation strategies, in terms of supply chains and inter-sectoral sustainable development policy. For example, if it was decided to use Miscanthus as the sole feed stock to achieve the policy target of $30 \%$ biomass co-firing in peat power stations, then 34,000 ha of land would need to be planted with Miscanthus, with a 3-year delay until peak yields are attained. The extent, and level, of government financial support for farmers will need to be carefully considered and targeted. The recently announced subsidies, directed towards 1400 ha in the first year, may be regarded as an informative pilot scheme.

Ultimately, the comparisons here were based on many assumptions, and used average values. Gross margins within Ireland vary widely according to variations in climate and soil type [41], and management practices on individual farms. Thus, the decision as to whether energy crops are an attractive alternative will vary among farms, and according to the views of individual farmers. However, data presented here indicate that SRCW and Miscanthus are promising substitutes to conventional land uses in an emerging era of area-based agricultural subsidy payments and higher energy prices. Future extension of the EU ETS may add further financial incentives for farmers to cultivate Miscanthus and SRCW, which have relatively low cultivation emissions and could enhance soil C sequestration [4].

\section{Conclusions}

On a per hectare basis, Miscanthus cultivation is more expensive than SRCW cultivation, owing to higher fertiliser requirements, annual harvest and a shorter lifetime over which establishment costs are absorbed. However, Miscanthus is anticipated to produce higher DM yields than SRCW, resulting in similar production costs per tonne DM. Conservative peak combustible yield estimates (after harvest and storage losses) of 14 and $10 \mathrm{t}^{-1} \mathrm{DM} \mathrm{ha}^{-1} \mathrm{a}^{-1}$ were applied to Miscanthus and SRCW economic analyses. Crop storage and drying are associated with the greatest uncertainty, and the choice of supply strategy results in variation of these and post-production transport, handling and combustion costs. For SRCW, producing wet wood chip for immediate sale is the most profitable supply strategy, even after prices were adjusted to reflect additional transport costs and reduced LHV compared with dried wood chip. These costs, borne by the consumer, may be mitigated if wood chip is used close to where it is produced, and if process heat can be used for drying (requires coordinated supply chain). Consequently, farmers may not need to reduce the farm-gate prices for wet wood chip supply, enabling higher revenues to be realised. Stick-harvest and outdoor drying may be the most realistic strategy, both from a whole-chain cost and energy-use perspective. For Miscanthus, chopped harvest is the cheaper supply strategy when compared with baling, but it may be associated with higher handling costs beyond the farm gate.

Profitability was highly dependent on production costs, and annualised gross margins became negative for some supply strategies when the highest cost estimates were applied. However, profitability was maintained, albeit diminished, when low yields were assumed, owing to the assumed proportionality of many costs to harvestable yield. Variations in the discount rate had a modest, but not critical, impact on discounted gross margins. Gross margins were critically dependent on the farm-gate price of biomass, though remained positive at the low end of the 70, 100 and $130 € \mathrm{t}^{-1} \mathrm{DM}$ range applied to both Miscanthus and SRCW. The mid price of $€ 100 \mathrm{t}^{-1} \mathrm{DM}$ is indicative of current circumstances in Ireland for wood chip, but is more speculative for Miscanthus, for which no real market yet exists. Predicted gross margins based on the market establishment efforts of one company are modest, and probably low compared with longer-term potential considering likely future demand for 'C-neutral' biomass fuels.

Compared with gross margins accruing from conventional agricultural land uses, many of which exhibited a marked decline in 2005 after subsidies were decoupled from production, energy crop gross margins predicted here are highly competitive. In particular, average cattle rearing, sugar beet and spring barley systems are forecast to return low or negative gross margins against which discounted energy crop returns of $€ 211-383 \mathrm{ha}^{-1} \mathrm{a}^{-1}$ are highly attractive. In addition, although not activating the EU biofuel production subsidy, energy crops grown on set-aside land do activate the set-aside subsidy, and generate a strong financial incentive for cultivation compared with the alternative cost burden of set-aside maintenance. The recently announced government subsidy 
scheme for Miscanthus and SRCW improves the likely returns from these crops, and, more importantly, considerably reduces the investment risk. However, the establishment of an energy-crop biomass market will require significantly higher establishment rates than envisaged under this new scheme.

In conclusion, the main barriers to energy crop production are the high upfront establishment costs in combination with long payback periods, lack of an established biomass market in Ireland associated with future price uncertainties, and a lack of policy coordination among sectors. Dissemination to farmers of energy crop knowledge and opportunities, and an extension of recently announced establishment subsidies in the context of coordinated policy, could promote a new market for energy-crop biomass in Ireland. Research and development work will be needed to identify optimum supply and utilisation strategies from a national perspective. Potential farmer and consumer financial benefits, combined with significant potential GHG emission reductions, should encourage government support for these crops.

\section{Acknowledgements}

The authors are grateful to the Irish Environmental Protection Agency for funding provided under the ERTDI 2000-2006 program. In addition, the authors are grateful to Dr. Thia Hennesy from the FAPRI-Ireland farm-level team for providing access to data on the outlook for conventional farming systems.

R E F E R E N C E S

[1] McGettigan M, Duffy P, Connolly N, O’Brien P. National inventory report 2006: greenhouse gas emissions 1990-2004 reported to the United Nations framework on climate change. Wexford: Environmental Protection Agency; 2006.

[2] Central Statistics Office website: 〈http://www.cso.ie/〉, last accessed May 2007.

[3] Howley M, O'Leary F, O'Gallachoir B. Energy in Ireland 1990-2004: Trends, issues, forecasts and indicators. Dublin: SEI; 2006.

[4] Styles D, Jones MB. Energy crops in Ireland: quantifying the potential life-cycle greenhouse gas reductions of energy-crop electricity. Biomass and Bioenergy 2007;31:759-72.

[5] Sustainable Energy Ireland. Co-firing with biomass (report prepared by Elekrowatt-Ekono). Dublin: SEI; 2004.

[6] Binfield J, Donnellan T, Hanrahan K, Westhoff P. The Luxembourg CAP reform agreement: implications for EU and Irish Agriculture. Dublin: Teagasc; 2003.

[7] Thorne FS. The impact of the 'Mid Term Review' on Irish tillage farms. In: Proceedings of the national tillage conference 2003. Carlow: Teagasc; 2003. p. 15-38.

[8] Thorne FS. Reform of the common market organisation for sugar: distributional impacts for Irish sugar beet producers. Agricultural Research Forum, Tullamore Court Hotel; 2006.

[9] Point carbon website: 〈http://www.pointcarbon.com/Home/ Market\%20prices/Historic\%20prices/article7342-390.html >, accessed May, 2007.

[10] EC. Directive 2003/87/EC of the European parliament and of the council of 13 October 2003.

[11] EC. Directive 2004/101/EC of the European parliament and of the council of 27 October 2004
[12] Styles D, Jones MB. Current and future competitiveness of electricity and heat from energy crops: a case study from Ireland. Energy Policy 2007;35:4355-67.

[13] Deurwaarder EP. Overview and analysis of national reports on the EU Biofuels Directive: prospects and barriers for 2005. The Netherlands: ECN; 2005.

[14] Heaton RJ, Randerson PF, Slater FM. The economics of growing short rotation coppice in the upland area of midWales and an economic comparison with sheep production. Biomass and Bioenergy 1999;17:59-71.

[15] Goor F, Jossart JM, Ledent JF. ECOP: an economic model to assess willow short rotation coppice global profitability in a case of small scale gasification pathway in Belgium. Environmental Modelling \& Software 2000;15:279-92.

[16] Ericsson K, Rosenqvist H, Ganko E, Pisarek M, Nilsson L. An agro-economic analysis of willow cultivation in Poland. Biomass and Bioenergy 2006;30:16-27.

[17] Rosenqvist H, Dawson M. Economics of willow growing in Northern Ireland. Biomass and Bioenergy 2005;28:7-14.

[18] Rosenqvist H, Dawson M. Economics of using wastewater irrigation of willow in Northern Ireland. Biomass and Bioenergy 2005;29:83-92.

[19] Department of Agriculture and Food. Minister Coughlan announces details of new bioenergy initiatives. 〈http://www. agriculture.gov.ie/index.jsp?file=pressrel/2007/18-2007.xml $\rangle$, accessed February 2007.

[20] Heaton EA, Clifton-Brown J, Voigt TB, Jones MB, Long SP. Miscanthus for renewable energy generation: European Union experience and projections for Illinois. Mitigation and Adoption Strategies for Global Change 2004;9:433-51.

[21] DEFRA (UK) Best practice guidelines for applicants to DEFRA's energy crops scheme. London: DEFRA; 2001.

[22] Bullard M. Economics of Miscanthus production. In: Jones M, Walsh B, editors. Miscanthus for energy and fibre. London: James and James; 2001 [Chapter 8].

[23] Quinns of Baltinglass. Personal communication by telephone, 30.01.2006.

[24] Lewandowski I, Heinz A. Delayed harvest of Miscanthusinfluences on biomass quantity and quality and environmental impacts of energy production. European Journal of Agronomy 2003;19:45-63.

[25] Rural generation. Description and costs for willow planting on grass ley. 〈http://www.ruralgeneration.comwww. ruralgeneration.com $\rangle$, accessed January 2006.

[26] Gigler JK, Meerdink G, Hendrix EMT. Willow supplystrategies to energy plants. Biomass and Bioenergy 1999;17:185-98.

[27] Venturi P, Gigler JK, Huisman W. Economical and technical comparison between herbaceous (Miscanthus $\times$ giganteus) and woody energy crops (Salix viminalis). Renewable Energy 1999;16:1023-6.

[28] Rosenqvist H, Aronsson P, Hasselgren K, Perttu K. Economics of using municipal wastewater irrigation of willow copice crops. Biomass and Bioenergy 1997; $12: 1-8$.

[29] Clifton-Brown JC, Neilson B, Lewandowski I, Jones MB. The modelled productivity of Miscanthus $\times$ giganteus (GREEF et DEU) in Ireland. Industrial Crops and Products 2000;12:97-109.

[30] Lewandowski I, Clifton-Brown J, Scurlock JMO, Huisman W. Miscanthus: European experience with a novel energy crop. Biomass and Bioenergy 2000;19:209-27.

[31] Kerry Biofuels website: 〈http://www.kbf.ie/fuel/plts_lse brites.htm $\rangle$, accessed March 2007.

[32] van Loo S, Koppejan J. Handbook of biomass combustion and co-firing. Enschede: Twente University Press; 2003.

[33] Connolly L, Kinsella A, Quinlan G, Moran B. National farm survey 2004. Dublin: Teagasc; 2005. 
[34] Breen J, Hennessy T. The impact of the MTR and the WTO reform on Irish farms. In: Outlook 2003, Medium term analysis for the agri-food sector. Dublin: Teagasc; 2003. p. 78-92 (Conference proceedings).

[35] Matthews RW. Modelling of energy and carbon budgets of wood fuel coppice systems. Biomass and Bioenergy 2001;21:1-19.

[36] Borjesson P. Environmental effects of energy crop cultivation in Sweden-I: identification and quantification. Biomass and Bioenergy 1999;16:137-54.

[37] Gigler JK, van Loon WKP, Sonneveld C. Experiment and modelling of parameters influencing natural wind drying of willow chunks. Biomass and Bioenergy 2004;26:507-14.

[38] Gigler JK, van Loon WKP, Vissers MM, Bot GPA. Forced convective drying of willow chips. Biomass and Bioenergy 2000;19:259-70.
[39] Rural Generation. Personal communication by telephone, 13.02.06.

[40] Londo M, Vleeshouwers L, Dekker J, de Graaf H. Energy farming in Dutch dessication abatement areas: yields and benefits compared to grass cultivation. Biomass and Bioenergy 2001;20:337-50.

[41] Clifton-Brown JC, Stampfl PF, Jones MB. Miscathus biomass production for energy in Europe and its potential contribution to decreasing fossil fuel carbon emissions. Global Change Biology 2004;10:509-18.

[42] DEFRA. Establishment costs for energy crops in England. 〈http://www.defra.gov.uk/farm/acu/pdf/cambridge-estabcosts.pdf $\rangle$, last accessed March 2006.

[43] van den Broek R, Teeuwisse S, Healion K, Kent T, van Wijk A, Faaij A, Turkenburg W. Potentials for electricity production from wood in Ireland. Biomass and Bioenergy 2001;26:991-1013. 